\title{
Effectiveness of zebra mussels to act as shelters from fish predators differs between native and invasive amphipod prey
}

\author{
Jarosław Kobak • Lukasz Jermacz • \\ Dariusz Płąchocki
}

Received: 14 April 2014/Accepted: 20 August 2014/Published online: 2 September 2014

(C) The Author(s) 2014. This article is published with open access at Springerlink.com

\begin{abstract}
Biological invasions cause organisms to face new predators, but also supply new anti-predator shelters provided by alien ecosystem engineers. We checked the level of anti-predator protection provided to three gammarid species by an invasive PontoCaspian zebra mussel Dreissena polymorpha, known for its habitat modification abilities. We used gammarids differing in their origin and level of association with mussels: Ponto-Caspian aliens Dikerogammarus villosus (commonly occurring in mussel beds) and Pontogammarus robustoides (not associated with mussels), as well as native European Gammarus fossarum (not co-occurring with dreissenids). The gammarids were exposed to predation of two fish species: the racer goby Babka gymnotrachelus (PontoCaspian) and Amur sleeper Perccottus glenii (Eastern Asian). This set of organisms allowed us to check whether the origin and level of association with mussels of both prey and predators affect the ability of
\end{abstract}

Handling Editor: Piet Spaak.

J. Kobak $(\bowtie) \cdot$ Ł. Jermacz

Department of Invertebrate Zoology, Faculty of Biology and Environmental Protection, Nicolaus Copernicus University, Lwowska 1, 87-100 Toruń, Poland e-mail: jkob73@umk.pl

D. Płąchocki

Department of Hydrobiology, Faculty of Biology and Environmental Protection, Nicolaus Copernicus

University in Torun, Lwowska 1, 87-100 Toruń, Poland gammarids to utilize zebra mussel beds as shelters. We tested gammarid survival in the presence of fish and one of five substrata: sand, macrophytes, stones, living mussels and empty mussel valves. D. villosus survived better than its congeners on all substrata, and its survival was highest in living dreissenids. The survival of the other gammarids was similar on all substrata. Both fish species exhibited similar predation efficiency. Thus, $D$. villosus, whose affinity to dreissenids has already been established, utilizes them as protection from fish predators, including allopatric predators, more efficiently than other amphipods. Therefore, the presence of dreissenids in areas invaded by $D$. villosus is likely to help the invader establish itself in a new place.

Keywords Dreissena polymorpha · Gammarids . Fish predation - Ponto-Caspian community · Biological invasions $\cdot$ Habitat type

\section{Introduction}

Gregarious bivalves often act as ecosystem engineers, exerting a multidirectional impact upon their environment by filtering suspended particles and increasing substratum heterogeneity (Karatayev et al. 2002). Many of them are highly successful invaders, changing local conditions in freshwater and marine environments all over the world (Karatayev et al. 2007; 
Dziubińska 2011; McDonald 2012). Bivalve ecosystem engineers affect macroinvertebrate communities by providing them with suitable food (pseudofaeces released by mussels) and anti-predator shelters among shells (Karatayev et al. 2002). Avoiding predators is crucial for the survival and fitness of prey organisms, which develop defence mechanisms to decrease predation risk (Lima and Dill 1990; Lass and Spaak 2003). The phenomenon of predator-prey interactions is particularly interesting in the case of alien species, which, on the one hand, can provide shelters for other invaders, supporting them in novel areas (van Overdijk et al. 2003; Gonzalez and Burkart 2004; Kobak et al. 2009) and, on the other hand, can offer new, previously unavailable anti-predator refugia for native prey (Gonzalez and Downing 1999; van Overdijk et al. 2003; DeVanna et al. 2011).

One of the most spectacular examples of gregarious bivalves with a great environmental impact is the zebra mussel Dreissena polymorpha (Pallas 1771), originating from the Ponto-Caspian region, but successfully colonizing freshwater systems of Europe and North America (Karatayev et al. 2002). On the one hand, it causes numerous economic and environmental problems throughout the world (Ram and Palazzolo 2008; Kelly et al. 2010), but on the other hand, it is known for increasing the abundance and richness of the bottom fauna associated with its colonies (Wolnomiejski 1970; Stewart et al. 1998; Karatayev et al. 2002). In particular, other alien organisms originating from the Ponto-Caspian region may benefit from the presence of zebra mussels in newly invaded areas (Ricciardi 2001; Gonzalez and Burkart 2004) and increase their invasive potential in accordance with the invasional meltdown hypothesis (Simberloff and Von Holle 1999). This hypothesis states that the number and overall strength of positive interactions among invasive species, particularly those originating from the same region, are greater than those of negative associations among them, which contributes to their invasion success. In other words, the higher the number of invasives in a given area, the greater the probability of success of future invasions. However, existing evidence shows that native species can also benefit from zebra mussel habitats (Stewart et al. 1999; Kestrup and Ricciardi 2009; DeVanna et al. 2011), leaving the question on the role of this bivalve in the invasional meltdown phenomenon open.
Several species have been found to be associated with zebra mussel colonies. This is particularly true for Ponto-Caspian gammarids, of which three species, Dikerogammarus villosus (Sovinsky, 1894), Dikerogammarus haemobaphes (Eichwald 1841) and Echinogammarus ischnus (Stebbing, 1899), have been observed to reach great densities in mussel aggregations in the field (Devin et al. 2003) and/or actively select mussel-related habitats in the laboratory (van Overdijk et al. 2003; Kobak et al. 2009, 2013). Gammarids inhabiting mussel colonies may benefit from the presence of multiple anti-predator shelters among living mussels and empty shells deposited on the bottom (Gonzalez and Burkart 2004), as well as from food sources provided by mussels (Gergs and Rothhaupt 2008). It is often assumed that organisms utilizing mussel colonies for anti-predator protection would select both living bivalves and empty shells increasing the availability of shelters on the bottom. On the other hand, species feeding on mussel products should prefer living mussels (Stewart et al. 1998; Mörtl and Rothhaupt 2003). Both these types of associations with bivalves have been exhibited by various gammarid species: for instance, D. haemobaphes and Gammarus roeselii Gervais, 1835 preferred living mussels (Mörtl and Rothhaupt 2003; Kobak et al. 2009), whereas Gammarus fasciatus Say, 1818 and Gammarus fossarum Koch, 1836 selected empty shells as well (Gonzalez and Downing 1999; Kobak and Żytkowicz 2007).

Ponto-Caspian gammarids invaded Europe in the last century (Jażdżewski et al. 2002), considerably affecting local environments due to their tolerance to wide ranges of environmental factors, gregariousness and omnivory with a strong tendency for predation (Devin and Beisel 2007; Grabowski et al. 2007; Bącela-Spychalska and van der Velde 2013). Thus, their environmental role clearly differs from that played by their native congeners, which undergo displacement by the aliens in areas of co-occurrence (Berezina and Panov 2003; MacNeil et al. 2011). Alien gammarids can affect abundance and taxonomic composition of benthic fauna (Berezina and Panov 2003), provide valuable food for fish (Grabowska and Grabowski 2005; Kakareko et al. 2005) and even modify the attachment or locomotion of zebra mussels among which they live (Platvoet et al. 2009; Kobak et al. 2012). That is why knowledge of their ecology in 
newly invaded areas, including their relationships with other alien species, is crucial for understanding the functioning of freshwater ecosystems.

In the present study, we aimed at testing the hypothesis that zebra mussel habitats would provide gammarids with a more efficient anti-predator shelter than other substrata available in the field, such as plants or stones (hypothesis 1). In particular, we intended to check whether living mussels would provide a better anti-predator protection compared to empty bivalve shells, as only the former create complex structures consisting of individuals byssaly connected with one another and with the bottom. Such structures may be more difficult to penetrate by a predator than other substrata. We also hypothesized that the species known for its associations with dreissenids (D. villosus) would utilize mussel habitats more efficiently than the others, especially native organisms, not co-evolving with Dreissena spp. for a long time. Moreover, we assumed that some gammarids would be more resistant to predation irrespective of shelter quality (hypothesis 2). Finally, we expected that a predator originating from the Ponto-Caspian region would be more efficient at foraging on PontoCaspian gammarids, particularly in zebra mussel habitats (hypothesis 3), as some specific adaptations could have evolved in the species co-existing with these bivalves. To verify these hypotheses, we conducted a series of laboratory experiments exposing three gammarid species (two Ponto-Caspian aliens and one native) differing from one another in their level of association with mussel beds to the predation of two benthivorous fish species (one sympatric and one allopatric to the Ponto-Caspian fauna) in the presence of several types of natural substrata, including living zebra mussels and their shells.

\section{Materials and methods}

Organisms

We chose two invasive Ponto-Caspian gammarids: Dikerogammarus villosus and Pontogammarus robustoides (G. O. Sars, 1894), which have recently expanded their range in Europe (Jażdżewski et al. 2002; Konopacka 2004), as well as a native European species, Gammarus fossarum (Jażdżewski 1975).
Among them, D. villosus has often been observed in great numbers in mussel habitats (Devin et al. 2003), $P$. robustoides has not shown any preferences for dreissenids, selecting other types of substrata (Kobak and Żytkowicz 2007), whereas G. fossarum usually does not co-occur with dreissenids, though it did exhibit a weak affinity for empty mussel shells in a laboratory experiment (Kobak and Żytkowicz 2007).

We collected the individuals of $D$. villosus by scuba diving together with zebra mussel colonies, plants and artificial substrata from the Włocławek Dam Reservoir (the Vistula River, Central Poland, GPS coordinates: $52.617784 \mathrm{~N}, 19.326994 \mathrm{E}$ ), at a depth of $0.5-2 \mathrm{~m}$. The individuals collected from this area belonged to the uniform dark colour morph of this species (Devin et al. 2004). Mean body length of the specimens used in our study was $10.2 \mathrm{~mm}$ (range 7.9-12.1 mm). Preliminary trials have shown that the fish used in our study had no problems with consuming gammarids within this size range. We captured the individuals of $P$. robustoides from the sandy nearshore bottom of the Włocławek Reservoir (the same location as above), at a depth of ca. $0.2-0.3 \mathrm{~m}$, using a 1-mm mesh hand net. Mean body length of the specimens used in our study was $9.5 \mathrm{~mm}$ (range 7.8-11.5 mm). Individuals of $G$. fossarum occurred in the Ruda River, a small tributary of the Włocławek Reservoir (GPS coordinates: $52.615218 \mathrm{~N}, 19.303014 \mathrm{E})$. We captured them with a 1-mm mesh hand net from the sandygravelly bottom covered by emergent macrophytes, at a depth of ca. $0.2-0.3 \mathrm{~m}$. Mean body length of the specimens used in our study was $7.4 \mathrm{~mm}$ (range $6.5-10.0 \mathrm{~mm}$ ). They were clearly smaller than the alien species used in our study, but this corresponds to the difference in size among these species and thus reflects the natural variability among them (Jażdżewski 1975; Konopacka 2004; Bacela and Konopacka 2005). Both invasive species were sampled from the localities in which zebra mussels or their shells were also present. Zebra mussels did not occur in the area of collecting of $G$. fossarum. In the laboratory, we placed the gammarids (each species separately) in 50-L tanks with sandy bottoms and plastic shelters, filled with dechlorinated, aerated tap water and located in an airconditioned room (temperature $21-23{ }^{\circ} \mathrm{C}$ ). They were provided with decaying tree leaves and chironomid larvae as food, so that they could satisfy their hunger regardless of their food preferences, varying with 
species and age (Berezina 2007; Mayer et al. 2008, 2012). Thus, the differences in hunger level among gammarids were unlikely to affect their responses in the presence of predators. We used the gammarids in the experiments within 1-3 weeks after collection.

We used two species of invasive fish, occurring in Europe since the 20th century: the racer goby Babka gymnotrachelus (Kessler, 1857), of Ponto-Caspian origin (thus sympatric to dreissenids and gammarids), and the Amur sleeper Perccottus glenii (Dybowski, 1877), coming from Eastern Asia (Grabowska et al. 2010). We collected the fish by electrofishing (IUP-12, Radet, Poznan, Poland) from the Włocławek Reservoir at a depth of $0.5-1 \mathrm{~m}$. The goby occurred on the sandy bottom in the area also inhabited by gammarids and zebra mussels, whereas the Amur sleeper lived in a muddy bay of the reservoir a few kilometres upstream from the site at which we collected the other organisms (GPS coordinates: 52.558351N, 19.555235E). Both species are versatile carnivores, including gammarids in their diverse diet (Grabowska and Grabowski 2005; Kakareko et al. 2005; Koščo et al. 2008; Grabowska et al. 2009). We used ten individuals of the goby and Amur sleeper, their mean size being $81 \mathrm{~mm}$ (range 69-102 $\mathrm{mm}$ ) and $85 \mathrm{~mm}(71-123 \mathrm{~mm}$ ), respectively. In the laboratory, we put the fish into 100-L tanks (each species separately, five individuals per tank) with dechlorinated, aerated tap water, gravelly bottoms and PVC half-tubes as shelters (one for each fish), located in an air-conditioned room (temperature $\left.21-23{ }^{\circ} \mathrm{C}\right)$. We used them in the experiments ca. 2 months after collection, when they had become acquainted with the laboratory conditions. Two weeks before the tests, we moved them to experimental tanks and started to add living gammarids (the species used in the experiment) to their usual diet (mainly frozen and living chironomid larvae) to make sure that the fish got used to the experimental conditions and gammarid prey.

\section{Substrata}

We used the following substrata in the experiments:

1. Living zebra mussels (mean length: $20.6 \mathrm{~mm}$, range $11.4-24.5 \mathrm{~mm}$ ) collected by scuba diving from the 1- to 2-m-deep sandy bottom of the Włocławek Reservoir (the same location as that from which gammarids were collected). We kept them in a 350-L aquarium filled with dechlorinated, aerated tap water in an air-conditioned room (temperature: $21-23{ }^{\circ} \mathrm{C}$ ). It should be noted that we did not observe production of pseudofaeces by mussels in experimental tanks during the tests.

2. Empty zebra mussel shells (mean length: $19.4 \mathrm{~mm}$, range 10.9-25.8 mm), collected together with living mussels or obtained from the individuals that died in the laboratory culture. We used single shell valves to simulate mussel shell litter that can be found in the wild.

3. Stones (mean length: $21.4 \mathrm{~mm}$, range $13.2-26.3 \mathrm{~mm}$ ) available commercially as substratum for aquarium fish. We exposed the stones in water for 2 weeks before the experiment to allow for the development of biofilm that was also present on the other objects used in the experiments. This period is sufficient for the growth of biofilm that attracts gammarids (Kobak et al. 2013).

4. Macrophytes (clasping-leaf pondweed Potamogeton perfoliatus L.) collected manually from the Włocławek Reservoir (the same location as that from which gammarids and mussels were taken).

5. Sand (mean grain diameter: $0.3 \mathrm{~mm}$ ), obtained from the nearshore zone of the Włocławek Reservoir (the same location as above).

We filled glass Petri dishes (diameter: $100 \mathrm{~mm}$, height: $20 \mathrm{~mm}$ ) with the substrata up to the brim (ca. 50 mussels and stones, 120 shell valves or $50 \mathrm{~cm}$ of coiled plant stems with leaves). We put an elastic rubber band across the diameter of each dish (Fig. 1) to prevent the plants from floating on the water surface. The mussels were separated from one another before use (to get rid of any organisms that could occur among them), put into the dishes and immersed in water ca. 6 days before the experiment so that they could form byssal bonds with each other and with the dish. This period is sufficient to create a firm connection with the substratum (Kobak 2006). The other dishes were treated similarly before use. The macrophytes and sand were rinsed thoroughly before using to get rid of any organisms and their remnants that could affect the behaviour of fish or gammarids. We used freshly prepared dishes and substrata in each experimental trial.

The use of 2-cm-thick substratum is justified, as it provided a sufficient level of habitat complexity, with 
Fig. 1 Experimental setup

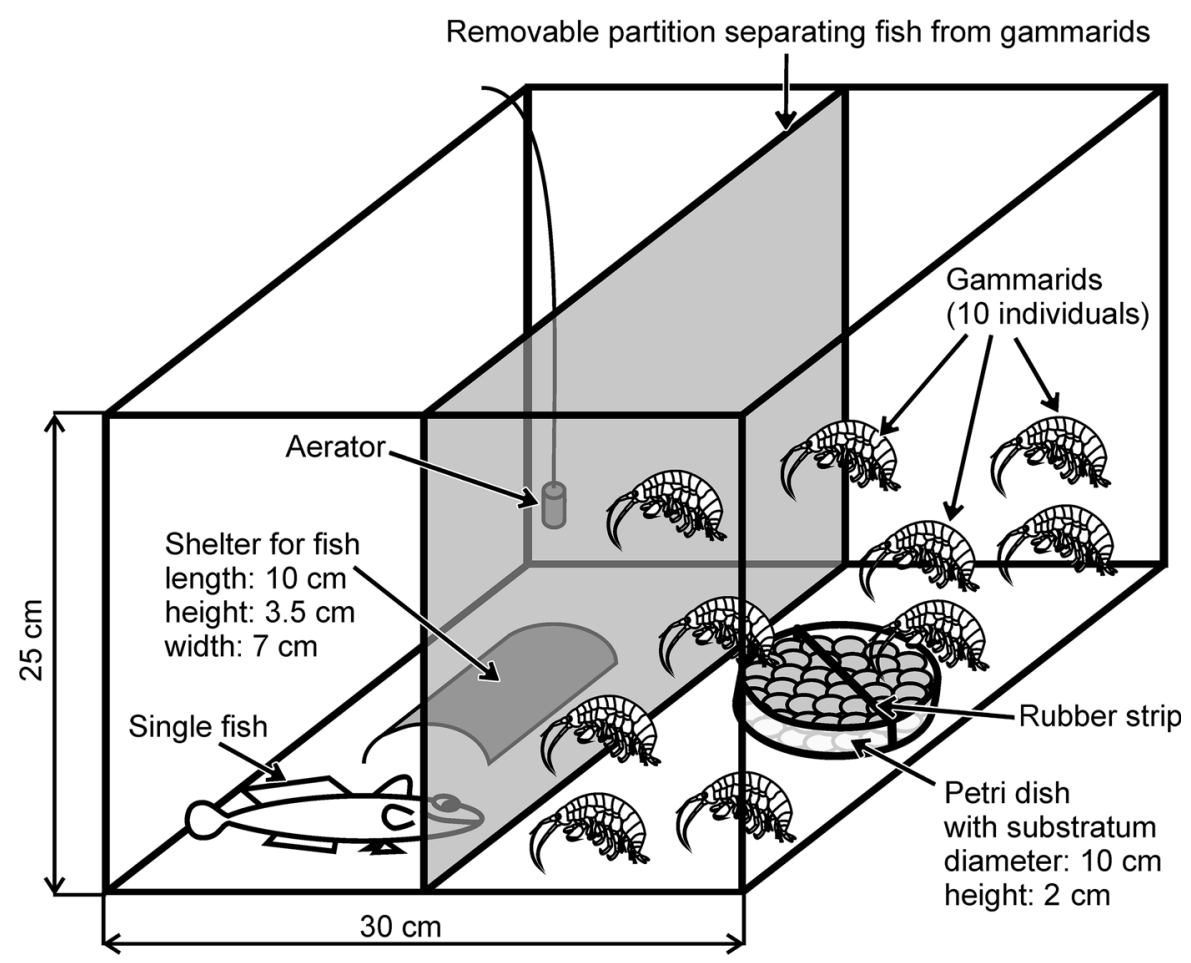

at least two or three layers of stones and living mussels attached to one another and several layers of shells forming a three-dimensional (3-D) structure. Poznańska et al. (2013) have shown that gammarids only bury in sand just below the surface (P. robustoides) or not at all (D. villosus and G. fossarum). Therefore, we assumed that further increasing the thickness of the substratum would not alter its quality as a shelter for gammarids. Visual observations before the experiments confirmed that the fish readily entered the dishes and searched for food in the substratum. Thus, the presence of the dishes did not affect the foraging modes of the fish.

\section{Experimental set-up}

We conducted the experiments in 22.5-L glass tanks (bottom: $30 \times 30 \mathrm{~cm}$, height: $25 \mathrm{~cm}$, water level ca. $20 \mathrm{~cm}$ ) filled with dechlorinated, aerated tap water. Each tank contained a single fish and a PVC half-pipe as a shelter. Before each trial, we divided the tank into two sectors with a removable glass partition and put a single dish filled with one of the above-mentioned substrata into the central part of one of the tank sectors. The fish, shelter and aerator were located in the other sector (Fig. 1). After that we fed the fish with frozen chironomids to standardize their hunger level. Food remnants were removed from the tank after feeding. After $24 \mathrm{~h}$, we put ten gammarids from one of the selected species into the part of the tank containing the substratum. The partition was not watertight on its edges, so the gammarids could sense the predator odours but could not move to the fish sector. One hour later, when the gammarids had taken their positions within the tank, we removed the glass partition, so that the fish gained free access to its prey. We removed the dish with substratum and counted gammarids that had survived $24 \mathrm{~h}$ later. This time allowed us to examine the long-term resistance of gammarids to predation, rather than short-term effects that could disappear after a longer exposure to fish (e.g. due to usual activity of gammarids exploring the area and returning to their shelters). In preliminary tests, we determined that the fish could easily consume more than ten gammarids in $24 \mathrm{~h}$; therefore, the satiation of the predators certainly did not affect gammarid survival in our experiment.

We checked the water quality parameters using a multimeter Multi340i (WTW GmbH, Weilheim, Germany). Water temperature (controlled by air- 
conditioning) was $22.6{ }^{\circ} \mathrm{C}$ (range $21.7-23.0^{\circ} \mathrm{C}$ ); conductivity, $486 \mu \mathrm{S} / \mathrm{cm}(417-525 \mu \mathrm{S} / \mathrm{cm}) ; \mathrm{pH} 8.6$ (8.4-8.7); and oxygen concentration, $7.1 \mathrm{mg} / \mathrm{L}$ $(6.9-7.3 \mathrm{mg} / \mathrm{L})$ or $83 \%(80-86 \%)$. The tanks were illuminated by natural light scattered by closed blinds in the window of the laboratory room. The illumination level was ca. 100-500 lx (luxometer L-20A, Sonopan Ltd., Białystok, Poland) at the water surface, depending on the weather. The photoperiod was natural (June-August).

We used ten individuals of each fish species. Each individual was consecutively exposed to each gammarid species $\times$ substratum type combination (altogether 15 trials with a single fish). The sequence of applying these combinations varied randomly among the fish. As all the fish were accustomed to consuming gammarids and their hunger level was standardized each time, the sequence was not likely to affect their predation success in consecutive trials.

Data analysis

We analysed the data using a three-way mixed design ANOVA, with fish species as a between-subjects factor and gammarid species and substratum type as within-subject factors. The use of within-subject design was necessary as the data were matched by particular fish individuals, each of them being exposed to each gammarid species $\times$ substratum combination. This allowed the number of fish specimens needed for the study to be reduced and made it possible to control for individual differences in feeding efficiency among them.

A significant substratum type effect (or its interaction with gammarid species, if the effect only existed for some species) would indicate a variable sheltering potential of the substrata used (hypothesis 1). Moreover, a significant main effect of gammarid species (with no interaction with substratum) would point to the variable survival of the tested gammarids independent of the substrata used (hypothesis 2). Any effects of Fish species or its interactions would indicate variable impacts of both species of fish on gammarid survival (hypothesis 3 ).

Log-transformed counts of gammarids consumed by particular fish individuals constituted a dependent variable. To control for the violation of a sphericity assumption, we applied a Greenhouse-Geisser correction to the results of the analysis. We further examined significant ANOVA effects using pairwise sequential-Bonferroni corrected $t$ tests (for paired or unpaired data, depending on the comparison).

The analyses were carried out using IBM SPSS Statistics v.21 package (ANOVA) or Microsoft Excel 2010 ( $t$ tests).

\section{Results}

The fish consumed $57 \%$ of all $D$. villosus individuals, $82 \%$ of $P$. robustoides individuals and almost all $G$. fossarum specimens $(98 \%)$. A significant gammarid species $\times$ substratum type interaction (Table 1) indicated that the studied substrata provided various gammarid species with different levels of protection (Fig. 2). D. villosus survived best among living zebra mussels (only $37 \%$ of consumed individuals), whereas sand was the least secure for this species (77\% of killed individuals). No significant differences among the substrata were found for the other gammarid species (Table 1).

In general, D. villosus survived better than the other species in the presence of both predators (Fig. 2; Table 1). Its advantage was most pronounced in a mussel bed and least visible on the worst, sandy substratum (Fig. 2). P. robustoides performed slightly better than G. fossarum, though only in the presence of the Amur sleeper, among living mussels and plants (Table 1).

The overall predation success did not differ significantly between both fish species (each of them consuming $79 \%$ of gammarids on average). A significant fish species $\times$ gammarid species interaction (Table 1) resulted from the fact that the Amur sleeper was relatively more successful than the racer goby in feeding on $P$. robustoides, while the tendency for D. villosus was the opposite (Fig. 2).

\section{Discussion}

We have demonstrated that zebra mussels provided gammarids with an effective protection against fish predation. However, an unambiguous positive effect of mussels was only observed in the case of Dikerogammarus villosus. In our study, gammarids were tested in the arena consisting of a dish with substratum, fish shelter and the remaining, open part of the 
Table 1 Mixed model ANOVA testing the effect of fish predation on gammarids occupying various substrata

\begin{tabular}{|c|c|c|c|c|c|}
\hline Effect $^{a}$ & $d f^{b}$ & MS & $F$ & $P$ & Post hoc $t$ tests ${ }^{\mathrm{c}, \mathrm{d}}$ \\
\hline Fish species $(F)^{B S}$ & 1 & $<0.01$ & 0.01 & 0.939 & \\
\hline Gammarid species $(\mathrm{G})^{\text {WS }}$ & $2(1.8)$ & 4.78 & 75.80 & $<0.001$ & \\
\hline $\mathrm{F} \times \mathrm{G}^{\mathrm{WS}}$ & $2(1.8)$ & 0.28 & 4.51 & 0.022 & $\begin{array}{l}\text { Bg: Dv } v^{\mathrm{x}}-\mathrm{Pr}^{\mathrm{y}}-\mathrm{Gf}^{\mathrm{y}} \\
\text { Pg: Dv }{ }^{\mathrm{x}}-\operatorname{Pr}^{\mathrm{y}}-\mathrm{Gf}^{\mathrm{z}} \\
\text { Dv, Pr, Gf: } B g^{\mathrm{x}}-\operatorname{Pg}^{\mathrm{x}}\end{array}$ \\
\hline Error & $36(32.4)$ & 0.06 & & & \\
\hline Substratum $(\mathrm{S})^{\mathrm{WS}}$ & $4(3.2)$ & 0.41 & 15.69 & $<0.001$ & \\
\hline $\mathrm{F} \times \mathrm{S}^{\mathrm{WS}}$ & $4(3.2)$ & 0.03 & 1.01 & 0.396 & \\
\hline Error & $72(57.0)$ & 0.03 & & & \\
\hline $\mathrm{G} \times \mathrm{S}^{\mathrm{WS}}$ & $8(4.3)$ & 0.18 & 5.48 & 0.001 & $\begin{array}{l}\text { Dv: } \mathrm{Sd}^{\mathrm{x}}-\mathrm{M}^{\mathrm{y}}-\mathrm{Sh}^{\mathrm{z}}-\mathrm{St}^{\mathrm{z}}-\mathrm{P}^{\mathrm{z}} \\
\text { Pr: } \mathrm{Sd}^{\mathrm{x}}-\mathrm{M}^{\mathrm{x}}-\mathrm{Sh}^{\mathrm{x}}-\mathrm{St}^{\mathrm{x}}-\mathrm{P}^{\mathrm{x}} \\
\text { Gf: } \mathrm{Sd}^{\mathrm{x}}-\mathrm{M}^{\mathrm{x}}-\mathrm{Sh}^{\mathrm{x}}-\mathrm{St}^{\mathrm{x}}-\mathrm{P}^{\mathrm{x}} \\
\text { Sd: } \mathrm{Dv} v^{\mathrm{x}}-\mathrm{Pr}^{\mathrm{x}}-\mathrm{Gf}^{\mathrm{y}} \\
\text { M, P: Dv }{ }^{\mathrm{x}}-\mathrm{Pr}^{\mathrm{y}}-\mathrm{Gf}^{\mathrm{z}} \\
\text { Sh, St: } \mathrm{Dv}{ }^{\mathrm{x}}-\mathrm{Pr}^{\mathrm{y}}-\mathrm{Gf}^{\mathrm{y}}\end{array}$ \\
\hline $\mathrm{F} \times \mathrm{G} \times \mathrm{S}^{\mathrm{WS}}$ & $8(4.3)$ & 0.02 & 0.69 & 0.607 & \\
\hline Error & $144(76.6)$ & 0.03 & & & \\
\hline
\end{tabular}

${ }^{a} B S$ between-subjects effect, $W S$ within-subject effect

b Values in parentheses are Greenhouse-Geisser corrected for sphericity

c Gammarids: Dv Dikerogammarus villosus, Pr Pontogammarus robustoides, Gf Gmmarus fossarum; Fishes: Bg Babka gymnotrachelus, Pg Perccottus glenii; Substrata: $S d$ sand, $M$ mussels, $S h$ shells, $S t$ stones, $P$ plants

${ }^{\mathrm{d}}$ Items labelled with the same superscript letter $(\mathrm{x}, \mathrm{y}, \mathrm{z})$ do not differ significantly $(P<0.05)$ from one another in sequentialBonferroni-corrected $t$ tests for paired data (comparisons among gammarids and substrata) or unpaired data (comparisons between fish species)

Fig. 2 Survival of gammarids in the presence of the studied substrata and predators. Substrata that did not differ from one another (sequential-Bonferroni corrected $t$ tests for paired data) with regard to the protection level offered to a given gammarid species are labelled with a horizontal bar in the same row at the bottom of the chart. Error bars are standard errors of the mean



could detect the presence of a predator before it was able to start foraging), (2) effectiveness of hiding in the provided substratum and (3) overall mobility (time bottom. Thus, better or worse utilization of a given habitat by a particular gammarid species depended on a combination of (1) its ability to locate a shelter (they 
spent in the shelter), which might depend on gammarid preferences for particular substrata. All these factors determine the quality of a given substratum as an anti-predator shelter for particular prey species. This reflects the situation experienced by animals in a patchy habitat in the field, where gammarids have to leave their shelters for some time to forage or reproduce, and their ability to find and use an available shelter determines their survival. Significant differences in survival among various substrata, found for a given gammarid species, clearly show that this species performed better in some habitats than in others. Such differences occurred in the case of D. villosus and zebra mussel habitat. D. villosus is known for its preferences for hard substrata (Boets et al. 2010), particularly zebra mussels (Devin et al. 2003) and other ecosystem-engineering bivalves, such as Corbicula sp. (Werner and Rothhaupt 2008). Kinzler and Maier (2006) showed that solid substratum (stones) provides $D$. villosus with better anti-predation protection than fine material (sand) and that this species can utilize such shelters better than native gammarids. Our study demonstrates that zebra mussels constitute even better shelter for $D$. villosus and greatly contribute to its survival in the presence of predatory fish.

Living zebra mussels can supply detritivores and predators with valuable food resources such as organic-rich pseudofaeces and abundant macroinvertebrate prey. Mussels also provide benthic macroinvertebrates with anti-predator shelters and hard substratum for attachment (Karatayev et al. 2002). D. villosus, being an omnivore with a strong tendency for predation (Berezina and Panov 2003) and, on the other hand, a valuable prey for benthivorous fish, may benefit from both these types of relationships with mussels. Gergs and Rothhaupt (2008) showed that $D$. villosus fed mussel pseudofaeces grew better than on plant detritus and achieved its maximum growth rate feeding on chironomid larvae, which in turn are known to reach greater densities in mussel beds (Mörtl and Rothhaupt 2003). Thus, feeding conditions in a mussel bed are particularly suitable for this gammarid. Moreover, our present study shows that D. villosus is better protected against predators in the presence of living mussels. Interestingly, empty shells, often regarded to be as good an anti-predator refugium for macroinvertebrates as living mussel beds, did not increase its survival compared to other potential shelters: stones and plants. Thus, the gammarids must have been protected by aggregations of mussels attached to the substratum and one another. Such a 3D structure was difficult to penetrate for fish searching for food. Indeed, the racer goby were observed in laboratory conditions to avoid zebra mussel substrata in favour of loose materials, such as gravel, stones, mud or sand (Kakareko 2011).

Dikerogammarus villosus might also benefit from its overall lower activity, compared to native species, such as G. fossarum (Kinzler and Maier 2006). Low activity and clinging to solid objects would be particularly beneficial in the presence of suitable shelters, where gammarids can stay in hiding. However, it does not seem to explain the advantage of living zebra mussel habitats over stones and empty shells, which offer similar numbers of crevices allowing gammarids to remain undetected.

Dikerogammarus villosus have very dark colouration, whereas other gammarid species used in our study are grey or light-grey. This might be another reason for the better positive effect of $D$. polymorpha upon D. villosus compared to its congeners, as the gammarids could find a perfect camouflage among similarly coloured, dark bivalves. The Amur sleeper is a visual predator, having large eyes and responding to moving objects (Reshetnikov 2008). The gobies are usually regarded as nocturnal predators (Grabowska and Grabowski 2005) feeding more often at night (Kakareko et al. 2013), but they also use visual cues during foraging (Diggins et al. 2002). Thus, both species are likely to decrease their predation success if their prey is hidden in a camouflaging substratum. However, the camouflage effect alone cannot explain the results obtained, as empty bivalve shells (of similar colouration) did not increase the protection level above that offered by stones and plants.

Our results provide evidence that mussel beds, avoided by potential predators (Kakareko 2011), are suitable anti-predator shelters for gammarids. Gammarids were observed to display a number of antipredator behaviours, such as avoidance and activity decrease in the presence of predator kairomones (Wudkevich et al. 1997; Baumgärtner et al. 2002), which probably increase their ability to protect themselves in available shelters. Such responses have also been shown in $D$. villosus, which avoids effluents from predatory fish and crayfish, as well as from injured conspecifics (Hesselschwerdt et al. 2009; Sornom et al. 2012). Active preferences for zebra 
mussel habitats, exhibited by Dikerogammarus sp. in laboratory conditions (Kobak and Żytkowicz 2007; Kobak et al. 2009), may also contribute to their antipredator defence mechanisms.

The other gammarids, Pontogammarus robustoides and Gammarus fossarum, which in our study did not utilize zebra mussel shelters as efficiently as $D$. villosus, showed no positive responses to dreissenid habitats (Kobak and Żytkowicz 2007). G. fossarum does not originate from the same region as zebra mussels and usually does not occur in areas occupied by mussel beds; thus, its ability to utilize that type of shelter and mussel pseudofaeces as food may be weaker. $P$. robustoides is a Ponto-Caspian species, but does not show any particular affinity for zebra mussel habitats, commonly inhabiting sandy areas and/or macrophyte beds (Żytkowicz et al. 2008). Perhaps that is why its ability to hide among mussels was lower than that of D. villosus. The adaptation of $P$. robustoides to survive disadvantageous circumstances by shallow burying into sandy substratum is not displayed by the other studied species (Poznańska et al. 2013). Indeed, this gammarid performed relatively well against the racer goby on sandy substratum (Fig. 2), though was unable to escape from the Amur sleeper, perhaps being a more efficient predator, with a larger mouth opening and better swimming skills. Thus, the level of association with zebra mussel habitats exhibited by various gammarid species (from frequent inhabitants to casual visitors) plays an important role in determining their ability to utilize mussel beds as shelters.

Theoretically, the observed variability in gammarid survival could also be affected by their cannibalism (Berezina and Panov 2003; MacNeil et al. 2008; Kinzler et al. 2009). However, we did not use the largest, most predatory individuals in our experiments and the size range of each species was rather narrow. Moreover, gammarids mainly prey on freshly moulted congeners (Kinzler et al. 2009). Given the relatively short time of our trials, the cases of moulting were uncommon during the exposure. Thus, cannibalism seems unlikely to affect the overall results.

Certainly, among the studied gammarids, D. villosus was the most resistant against predation, irrespective of the predator species and substratum type, though its advantage over the other species was lowest on sand (offering the weakest level of protection). $D$. villosus, having particularly powerful claws and displaying a tendency to cling strongly to various solid objects, might be quite difficult to detach by a predator, which could explain its success relative to the other species. G. fossarum was consumed almost totally on all substratum types. This might be accounted for by its weaker defensive mechanisms and/or smaller size of the individuals of this species used in the present study. The latter fact actually reflects the natural differences in size between $G$. fossarum and both alien gammarids occurring in the field (Jażdżewski 1975; Konopacka 2004; Bạcela and Konopacka 2005); therefore, such a choice of individuals for the experiment is justified. On the other hand, the differences in size cannot explain the variable survival of $D$. villosus and $P$. robustoides, which were of similar sizes in our experiment. Moreover, species-specific differences in mobility (time spent outside the shelter) among the studied gammarids could contribute to the observed differences in predation efficiency, with the most active species, often leaving their shelters, being predated more often. In fact, G. fossarum is known to be more active than D. villosus and therefore exposed to a higher fish predation risk, particularly in the presence of solid substratum (Kinzler and Maier 2006). It should be noted, however, that activity alone cannot explain the differences in survival within a particular gammarid species on various substrata, which definitely point to the variable quality of the materials used as anti-predator shelters.

We did not observe any pronounced differences in overall predation success between both fish species used in our study. Although both of them are alien in Europe, the racer goby is sympatric with zebra mussels, D. villosus and $P$. robustoides, originating from the Ponto-Caspian region, whereas the Amur sleeper, of Eastern Asian origin, had no common evolutionary history with any of them before they had met in their novel European areas. In such cases, it can be expected that a sympatric predator will be more efficient at hunting its prey, though, on the other hand, defensive mechanisms of prey can be ineffective against an unknown predator. In our study, these opposite tendencies may have resulted in the observed lack of significant differences in predation success between fish species.

Our observations on the predation efficiency of the racer goby and Amur sleeper feeding on the Ponto- 
Caspian gammarids are particularly important as both fish species seem to increase their ranges and numbers in Europe, becoming an important part of local ecosystems with a great environmental impact (Erös et al. 2005; Kakareko et al. 2009; Grabowska et al. 2010). Thus, the possibility of finding a suitable shelter against their predation may be crucial for the survival and invasion success of their potential gammarid prey.

Another Dikerogammarus species, D. haemobaphes, was found in the previous studies to prefer mussel beds over other hard substrata, such as empty shells and stones, using cues associated with shell periostracum and biofilm (Kobak et al. 2009, 2013). Similar preferences were observed in Echinogammarus ischnus, another Ponto-Caspian gammarid successfully extending its range beyond its native region (van Overdijk et al. 2003). This suggests that zebra mussels can affect positively other alien species, particularly those originating from their native Ponto-Caspian region, and contribute to their invasion success, which would support the invasional meltdown hypothesis (Ricciardi 2001). Though this might be true in the case of the above-mentioned species, several local organisms, without a long common evolutionary history with dreissenids, such as an American gammarid, Gammarus fasciatus (Kestrup and Ricciardi 2009), a mayfly Hexagenia sp. (DeVanna et al. 2011) and a snail Physella heterostropha (Stewart et al. 1999), also show active preferences for living mussels and/ or their shells. Nevertheless, in our study a native species turned out to be less efficient in utilizing mussel habitats and surviving predation compared to its Ponto-Caspian congener. Thus, zebra mussels can play an important role in supporting the spread of alien Dikerogammarus species, which are particularly well adapted to utilize all the benefits offered by mussels in newly invaded areas. Given the considerable impact of alien gammarids upon freshwater communities (Bacela-Spychalska and van der Velde 2013), this effect of the zebra mussel may be yet another field in which this species strongly affects aquatic ecosystems.

Acknowledgments Our research was supported by a Grant of the Polish Ministry of Science and Higher Education No. N N304 3930 38. We are grateful to Mrs Hazel Pearson for language corrections.
Open Access This article is distributed under the terms of the Creative Commons Attribution License which permits any use, distribution, and reproduction in any medium, provided the original author(s) and the source are credited.

\section{References}

Baccela K, Konopacka A (2005) The life history of Pontogammarus robustoides, an alien amphipod species in Polish waters. J Crust Biol 25:190-195

Baccela-Spychalska K, van der Velde G (2013) There is more than one 'killer shrimp': trophic positions and predatory abilities of invasive amphipods of Ponto-Caspian origin. Freshw Biol 58:730-741

Baumgärtner D, Jungbluth AD, Koch U, von Elert E (2002) Effects of infochemicals on microhabitat choice by the freshwater amphipod Gammarus roeseli. Arch Hydrobiol 155:353-367

Berezina NA (2007) Food spectra and consumption rates of four amphipod species from the North-West of Russia. Fundam Appl Limnol 168:317-326

Berezina NA, Panov VE (2003) Establishment of new gammarid species in the eastern Gulf of Finland (Baltic Sea) and their effects on littoral communities. Proc Estonian Acad Sci Biol Ecol 52:284-304

Boets P, Lock K, Messiaen M, Goethals PLM (2010) Combining data-driven methods and lab studies to analyse the ecology of Dikerogammarus villosus. Ecol Inform 5:133-139

DeVanna KM, Armenio PM, Barrett CA, Mayer CM (2011) Invasive ecosystem engineers on soft sediment change the habitat preferences of native mayflies and their availability to predators. Freshw Biol 56:2448-2458

Devin S, Beisel JN (2007) Biological and ecological characteristics of invasive species: a gammarid study. Biol Invasions 9:13-24

Devin S, Piscart C, Beisel JN, Moreteau JC (2003) Ecological traits of the amphipod invader Dikerogammarus villosus on a mesohabitat scale. Arch Hydrobiol 158:43-56

Devin S, Bollache L, Beisel JN, Moreteau JC, Perrot-Minnot MJ (2004) Pigmentation polymorphism in the invasive amphipod Dikerogammarus villosus: some insights into its maintenance. J Zool 264:391-397

Diggins TP, Kaur J, Chakraborti RK, DePinto JV (2002) Diet choice by the exotic round goby (Neogobius melanostomus) as influenced by prey motility and environmental complexity. J Great Lakes Res 28:411-420

Dziubińska A (2011) Mytilopsis leucophaeata, an alien dreissenid bivalve discovered in the Gulf of Gdańsk (southern Baltic Sea). Oceanologia 53:651-655

Erös T, Sevcsik A, Tòth B (2005) Abundance and night-time habitat use patterns of Ponto-Caspian gobiid species (Pisces, Gobiidae) in the littoral zone of the River Danube, Hungary. J Appl Ichthyol 21:350-357

Gergs R, Rothhaupt KO (2008) Feeding rates, assimilation efficiencies and growth of two amphipod species on biodeposited material from zebra mussels. Freshw Biol 53:2494-2503 
Gonzalez M, Burkart G (2004) Effects of food type, habitat and fish predation on the relative abundance of two amphipod species, Gammarus fasciatus and Echinogammarus ischnus. J Great Lakes Res 30:100-113

Gonzalez M, Downing A (1999) Mechanisms underlying amphipod responses to zebra mussel (Dreissena polymorpha) invasion and implications for fish-amphipod interactions. Can J Fish Aquat Sci 56:679-685

Grabowska J, Grabowski M (2005) Indications on the diel feeding activity in early summer of racer goby Neogobius gymnotrachelus (Gobiidae)-a new invader in the Baltic basin. J Appl Ichthyol 21:282-286

Grabowska J, Grabowski M, Pietraszewski D, Gmur J (2009) Nonselective predator-the versatile diet of Amur sleeper (Perccottus glenii Dybowski, 1877) in the Vistula River (Poland), a newly invaded ecosystem. J Appl Ichthyol 25:451-459

Grabowska J, Kotusz J, Witkowski A (2010) Alien invasives fish species in Polish waters: an overview. Folia Zool 59:73-85

Grabowski M, Bạcela K, Konopacka A (2007) How to be an invasive gammarid (Amphipoda: Gammaroidea)—comparison of life history traits. Hydrobiologia 590:75-84

Hesselschwerdt J, Tscharner S, Necker J, Wantzen KM (2009) A local gammarid uses kairomones to avoid predation by the invasive crustaceans Dikerogammarus villosus and Orconectes limosus. Biol Invasions 11:2133-2140

Jażdżewski K (1975) Morfologia, taksonomia i występowanie w Polsce kiełży z rodzajów Gammarus Fabr. i Chaetogammarus Mart. (Crustacea, Amphipoda). Acta Univ Lodz, Łódź, Poland

Jażdżewski K, Konopacka A, Grabowski M (2002) Four PontoCaspian and one American gammarid species (Crustacea, Amphipoda) recently invading Polish waters. Contrib Zool 71:115-122

Kakareko T (2011) Wpływ wybranych czynników na rozmieszczenie i preferencje siedliskowe babki łysej (Neogobius gymnotrachelus Kessler, 1857) i babki szczupłej (Neogobius fluviatilis Pallas, 1811), obcych gatunków ryb w Polsce. [Impact of selected factors on the distribution and habitat preferences of two non-native fish species in Poland: racer goby Neogobius gymnotrachelus and monkey goby Neogobius fluviatilis], Wydawnictwo Naukowe UMK, Torun, Poland

Kakareko T, Żbikowski J, Żytkowicz J (2005) Diet partitioning in summer of two syntopic neogobiids from two different habitats of the lower Vistula River, Poland. J Appl Ichthyol 21:292-295

Kakareko T, Płąchocki D, Kobak J (2009) Relative abundance of Ponto-Caspian gobiids in the lower Vistula River (Poland) 3 to 4 years after first appearance. J Appl Ichthyol 25:647-651

Kakareko T, Kobak J, Grabowska J, Jermacz Ł, Przybylski M, Poznańska M, Pietraszewski D, Copp GH (2013) Competitive interactions for food resources between invasive racer goby Babka gymnotrachelus and native European bullhead Cottus gobio. Biol Invasions 15:2519-2530

Karatayev AY, Burlakova LE, Padilla DK (2002) Impacts of zebra mussels on aquatic communities and their role as ecosystem engineers. In: Leppäkoski E, Gollasch E, Olenin $\mathrm{S}$ (eds) Invasive aquatic species of Europe: distribution, impacts and management. Kluwer Academic Publishers, Boston, pp 433-446

Karatayev AY, Boltovskoy D, Padilla DK, Burlakova LE (2007) The invasive bivalves Dreissena polymorpha and Limnoperna fortunei: parallels, contrasts, potential spread and invasion impacts. J Shellfish Res 26:205-213

Kelly DW, Hermorg LM, MacIsaac HJ (2010) Ecosystem changes associated with Dreissena invasions: recent developments and emerging issues. In: van der Velde G, Rajagopal S, bij de Vaate A (eds) The zebra mussel in Europe. Backhuys Publishers, Leiden, Margraf Publishers, Weikersheim. pp 199-209

Kestrup A, Ricciardi A (2009) Are interactions among PontoCaspian invaders driving amphipod species replacement in the St. Lawrence River? J Great Lakes Res 35:392-398

Kinzler W, Maier G (2006) Selective predation by fish: a further reason for the decline of native gammarids in the presence of invasives? J Limnol 65:27-34

Kinzler W, Kley A, Mayer G, Waloszek D, Maier G (2009) Mutual predation between and cannibalism within several freshwater gammarids: Dikerogammarus villosus versus one native and three invasives. Aquat Ecol 43:457-464

Kobak J (2006) Factors influencing the attachment strength of Dreissena polymorpha (Bivalvia). Biofouling 22:141-150

Kobak J, Żytkowicz J (2007) Preferences of invasive PontoCaspian and native European gammarids for zebra mussel (Dreissena polymorpha, Bivalvia) shell habitat. Hydrobiologoia 589:43-54

Kobak J, Kakareko T, Poznańska M, Żbikowski J (2009) Preferences of the Ponto-Caspian amphipod Dikerogammarus haemobaphes for living zebra mussels. J Zool 279:229-235

Kobak J, Poznańska M, Kakareko T (2012) Behavioural changes of zebra mussel Dreissena polymorpha (Bivalvia) induced by Ponto-Caspian gammarids. Biol Invasions 14:1851-1863

Kobak J, Kakareko T, Jermacz Ł, Poznańska M (2013) The impact of zebra mussel (Dreissena polymorpha) periostracum and biofilm cues on habitat selection by a PontoCaspian amphipod Dikerogammarus haemobaphes. Hydrobiologia 702:215-226

Konopacka A (2004) Inwazyjne skorupiaki obunogie (Crustacea, Amphipoda) w wodach Polski [Invasive amphipods (Crustacea, Amphipoda) in Polish waters]. Prz Zool 48:141-162

Koščo J, Manko P, Miklisová D, Košuthová L (2008) Feeding ecology of invasive Perccottus glenii (Perciformes, Odontobutidae) in Slovakia. Czech J Anim Sci 53:479-486

Lass S, Spaak P (2003) Chemically induced anti-predator defences in plankton: a review. Hydrobiologia 491:221-239

Lima SL, Dill LM (1990) Behavioral decisions made under the risk of predation: a review and prospectus. Can J Zool 68:619-640

MacNeil C, Platvoet D, Dick JTA (2008) Potential roles for different body size and microhabitat complexity in mediating biotic interactions within invasive freshwater amphipod assemblages. Fundam Appl Limnol 172:175-182

MacNeil C, Dick JTA, Platvoet D, Briffa M (2011) Direct and indirect effects of species displacements: an invading freshwater amphipod can disrupt leaf-litter processing and shredder efficiency. J N Am Benthol Soc 30:38-48 
Mayer G, Maier G, Maas A, Waloszek D (2008) Mouthparts of the Ponto-Caspian invader Dikerogammarus villosus (Amphipoda: Pontogammaridae). J Crust Biol 28:1-15

Mayer G, Maas A, Waloszek D (2012) Mouthpart morphology of three sympatric native and nonnative gammaridean species: Gammarus pulex, G. fossarum, and Echinogammarus berilloni (Crustacea: Amphipoda). Int J Zool. doi: $10.1155 / 2012 / 493420$

McDonald J (2012) Detection of the tropical mussel species Perna viridis in temperate Western Australia: possible association between spawning and a marine heat pulse. Aquat Invasions 7:483-490

Mörtl M, Rothhaupt KO (2003) Effects of adult Dreissena polymorpha on settling juveniles and associated macroinvertebrates. Int Rev Hydrobiol 88:561-569

Platvoet D, van der Velde G, Dick JTA, Li SQ (2009) Flexible omnivory in Dikerogammarus villosus (Sowinsky, 1894) (Amphipoda) - amphipod pilot species project (AMPIS) Report 5. Crustaceana 82:703-720

Poznańska M, Kakareko T, Krzyżyński M, Kobak J (2013) Effect of substratum drying on the survival and migrations of Ponto-Caspian and native gammarids (Crustacea: Amphipoda). Hydrobiologia 700:47-59

Ram JL, Palazzolo SM (2008) Globalization of an aquatic pest: economic costs, ecological outcomes, and positive applications of zebra mussel invasions and expansions. Geogr Compass 2:1755-1776

Reshetnikov AN (2008) Does rotan Perccottus glenii (Perciformes: Odontobutidae) eat the eggs of fish and amphibians? J Ichthyol 48:336-344

Ricciardi A (2001) Facilitative interactions among aquatic invaders: is an "invasional meltdown" occurring in the Great Lakes? Can J Fish Aquat Sci 58:2513-2525

Simberloff D, Von Holle B (1999) Positive interactions of nonindigenous species: invasional meltdown? Biol Invasions 1:21-32
Sornom P, Gismondi E, Vellinger C, Devin S, Férard JF, Beisel JN (2012) Effects of sublethal cadmium exposure on antipredator behavioural and antitoxic responses in the invasive amphipod Dikerogammarus villosus. PLoS One 7(8):e42435. doi:10.1371/journal.pone.0042435

Stewart TW, Miner JG, Lowe RL (1998) Quantifying mechanisms for zebra mussel effects on benthic macroinvertebrates-organic matter production and shell-generated habitat. J N Am Benthol Soc 17:81-94

Stewart TW, Gafford JC, Miner JG, Lowe RL (1999) Dreissenashell habitat and antipredator behavior: combined effects on survivorship of snails co-occurring with molluscivorous fish. J N Am Benthol Soc 18:274-283

Van Overdijk CDA, Grigorovich IA, Mabee T, Ray WJ, Ciborowski JH, MacIsaac HJ (2003) Microhabitat selection by invasive amphipod Echinogammarus ischnus and native Gammarus fasciatus in laboratory experiments and in Lake Erie. Freshw Biol 48:567-578

Werner S, Rothhaupt KO (2008) Effects of the invasive Asian clam Corbicula fluminea on benthic macroinvertebrate taxa in laboratory experiments. Fundam Appl Limnol 173:145-152

Wolnomiejski N (1970) The effects of Dreissena polymorpha Pall. aggregation on the differentiation of the benthonic macrofauna. Acta Univ N Copernici Limnol Pap 5:31-39

Wudkevich K, Wisenden BD, Chivers DP, Smith JF (1997) Reactions of Gammarus lacustris to chemical stimuli from natural predators and injured conspecifics. J Chem Ecol 23:1163-1173

Żytkowicz J, Kobak J, Kakareko T, Kentzer A (2008) Species composition and distribution of invasive Ponto-Caspian amphipods in the off-channel microhabitats of a temperate, lowland dam reservoir. Int Rev Hydrobiol 93:62-72 